\title{
Starzenie się społeczeństw i migracja - dwa główne wyzwania Europy w II dekadzie XXI wieku. Czy jesteśmy gotowi na zmiany?
}

\begin{abstract}
Wstęp
Dwudziesty pierwszy wiek dostarcza Europie oraz reszcie świata wyzwań społeczno-ekonomicznych nie znanych w dotychczasowych dziejach ludzkości, z uwagi na ich skalę oraz wzajemne powiązania. Autor artykułu, korzystając z możliwości, jakie stwarzają narzędzia komparatystyki politologicznej (comperative politics) (Rubinson, Ragin, 2007), zwłaszcza zbliżone do analizy kompleksowej (Geyer, 2003) oraz podejście jakościowej analizy komparatywnej (QCA), postara się odpowiedzieć na kilka istotnych pytań badawczych, związanych z wzajemnymi relacjami pomiędzy dwoma pozornie sprzecznymi zjawiskami. Czy współczesna Europa może sprostać wyzwaniom starzejących się społeczeństw przy uwzględnieniu czynników związanych ze współczesną migracją? Jakie uwarunkowania i wyzwania czekają państwa i społeczeństwa europejskie w związku z narastaniem tych procesów? Czy proponowane rozwiązania mogą być uniwersalne?

Ponieważ porównanie nie musi, a w powiązaniu z podejściem charakterystycznym dla analizy kompleksowej, nie powinno dążyć do zbytniego spłaszczenia zmiennych będących przedmiotem analizy, w opracowaniu zostaną wykorzystane wybrane przykłady globalne, europejskie oraz jednostkowe, nawiązujące do sytuacji w poszczególnych państwach. Bardzo istotnym przedmiotem analizy są materiały statystyczne odnoszące się do problemów demograficznych, zwłaszcza starzenia społeczeństw oraz migracji.
\end{abstract}

\section{Europa i świat starzejących się współobywateli}

Na samym wstępie należy zauważyć, iż Europa nie jest samotną wyspą zmagającą się z problemem starzenia społeczeństw. Obecnie uważa się, iż cywilizacja ludzka nie zaznała w swoich dziejach takiej rewolucji demograficznej, jak obecne procesy starzenia się społeczeństw odczuwalne od początku XXI wieku. Jest to problem fundamentalny dla rozwoju wielu społeczeństw, państw i regionów z uwagi na jego wpływ na procesy społeczno-ekonomiczne (Harper, 2006).

Prognoza dotycząca postępującego starzenia się świata jest wręcz katastroficzna, jest to tym bardziej trudne do zrozumienia, gdy porównamy to z perspektywą zaistniałą 
w II połowie XX wieku, wtedy to właśnie patrzyliśmy z lękiem ${ }^{1}$ na możliwość przyrostu ludności oraz problemy przeludnienia świata. Warto w tym miejscu przypomnieć, iż w latach 50-tych XX wieku ludzkość liczyła niespełna 2,5 miliarda ludzi. Gdy wzrost ludności postępował, to pod koniec stulecia, na fali niepokojów w 1979 roku Chiny ustanowiły limit jednego dziecka, nakładając na rodziny niestosujące się do tego nakazu, wysokie kary. Nikt wtedy nie przypuszczał, iż już w II dekadzie XXI wieku, w tych samych Chinach na bezpieczeństwo państwa będzie się z niepokojem patrzeć, ale z perspektywy niskiego przyrostu demograficznego oraz starzenia się społeczeństwa (China 2030, 2013).

Patrząc na kwestie zmian dotyczących Europy i świata warto skonfrontować ze sobą dane statystyczne dotyczące przyrostu naturalnego oraz długości życia, zauważalne w skali globalnej, a nie tylko regionalnej. Trzeba przy tym zauważyć, iż diametralnie zmienia się podejście do kwestii długości życia, a tym samym starzenia się i samej kategorii ludzi starych ${ }^{2}$.

Organizacja Narodów Zjednoczonych zajęła się problemem gwałtownego starzenia społeczeństw już w latach 80-tych XX wieku. W 1982 roku w Wiedniu zwołane zostało Pierwsze Światowe Zgromadzenie ONZ poświęcone procesom starzenia się społeczeństw. Wykorzystując możliwości prognozowania ONZ stwierdziła, iż globalna populacja osób powyżej 60 roku życia wzrośnie w roku 2025 o 224\%, porównując do roku 1975. Natomiast globalna populacja ogółem, jedynie o 102\%. Charakterystyczny, rzadko podnoszony w debacie publicznej społeczeństw wysokorozwiniętych jest fakt, iż populacja ludzi starszych wzrasta bardzo dynamicznie w krajach rozwijających się. Według prognoz ONZ w 2025 roku ma to być 72\% ogółu populacji, tymczasem w 1975 roku było to niespełna $52 \%$. Według tej samej prognozy ilość osób poniżej 15 roku życia ma spaść w tych regionach świata z 41\% w 1975 roku, do 26\% w 2025. Zmienia to diametralnie wyobrażenie o proporcjach pokoleniowych wśród społeczeństw rozwijających się (Vienna International Plan of Action on Aging, 1983). Po 20 latach, na II Światowym Szczycie ONZ z 2002 roku odbywającym się w Madrycie, uczestniczyło 156 państw. Już na samym wstępie dokumentu przygotowanego przez Szczyt uwypuklona jest refleksja, iż w porównaniu z rokiem 1982 świat uległ zdecydowanym zmianom, zauważanym z perspektywy starzenia się społeczeństw. Możemy przeczytać, że „[..] dzisiaj rozumiemy, iż dramatyczne zmiany demograficzne mają głębokie konsekwencje we wszystkich płaszczyznach życia indywidualnego, zbiorowego, narodowego i międzynarodowego" (Political Declaration, 2002, s. 4). W odniesieniu do perspektywy sięgającej roku 2050, prognozuje się w nim, iż światowa populacja osób powyżej 60 roku życia podwoi się, natomiast w krajach rozwijających się wzrośnie czterokrotnie. Łącznie będą oni stanowili 21\% mieszkańców Ziemi. Ilościowo będzie to blisko 2 miliardy ludzi.

1 W filmie „Soylent Green” (,Zielona Pożywka”) z roku 1973 przedstawiono widzom przerażający obraz. W 2022 świat mialby być tak przeludniony, że wygłodniale masy zwrócilyby się w stronę kanibalizmu.

2 Formułując wnioski dotyczące starzejących się spoleczeństw należy mieć na uwadze, iż w literaturze odnoszącej się do tej problematyki występują podziały na grupy młodych-starych (65-74), starszych-starych (75-84) i prawdziwie starych (85 i więcej lat). Pojawia się również określenie Trzeciego i Czwartego wieku. 
Zestawienia poniżej wskazują, jak dynamicznie zmienia się populacja osób starszych zarówno z perspektywy minionych dekad, jak też prognoz sięgających drugiej połowy XXI wieku.

Tabela 1

Populacja osób w wieku starszym 1950-2050. Podzial na regiony ONZ w milionach

\begin{tabular}{|l|r|r|r|r|r|r|r|r||}
\hline \multirow{2}{*}{ Region } & \multicolumn{3}{|c|}{ Populacja w wieku 65 i więcej } & \multicolumn{3}{c|}{ Populacja w wieku 80 i więcej } \\
\cline { 2 - 10 } & $\mathbf{1 9 5 0}$ & $\mathbf{2 0 0 0}$ & $\mathbf{2 0 2 5}$ & $\mathbf{2 0 5 0}$ & $\mathbf{1 9 5 0}$ & $\mathbf{2 0 0 0}$ & $\mathbf{2 0 2 5}$ & $\mathbf{2 0 5 0}$ \\
\hline Świat & 131 & 417 & 832 & 1,487 & 15 & 70 & 161 & 395 \\
\hline Rozwinięte & 64 & 172 & 266 & 334 & 8 & 37 & 71 & 121 \\
\hline Rozwijające się & 67 & 246 & 566 & 1,153 & 6 & 33 & 90 & 274 \\
\hline Afryka & 7 & 27 & 59 & 142 & 1 & 3 & 7 & 21 \\
\hline Azja & 57 & 211 & 472 & 906 & 5 & 29 & 81 & 228 \\
\hline Europa & 45 & 107 & 152 & 189 & 6 & 22 & 39 & 66 \\
\hline Ameryka Lacińska i Karaiby & 6 & 30 & 71 & 142 & 1 & 6 & 15 & 40 \\
\hline Ameryka Północna & 14 & 40 & 73 & 98 & 2 & 10 & 17 & 36 \\
\hline Oceania & 1 & 3 & 6 & 10 & 0 & 1 & 2 & 3 \\
\hline
\end{tabular}

Źródto: United Nations (2009), World population prospects: The 2008 revision population database, United Nations, Department of Economic and Social Affairs, Population Division, New York.

Tabela 2

Przyrost populacji osób w wieku starszym 1950-2050. Podzial na regiony ONZ w \%

\begin{tabular}{||l|c|c|c|c|c|c|c|c||}
\hline \multirow{2}{*}{ Region } & \multicolumn{3}{|c|}{ Populacja w wieku 65 i więcej } & \multicolumn{3}{c||}{ Populacja w wieku 80 i więcej } \\
\cline { 2 - 10 } & $\mathbf{1 9 5 0}$ & $\mathbf{2 0 0 0}$ & $\mathbf{2 0 2 5}$ & $\mathbf{2 0 5 0}$ & $\mathbf{1 9 5 0}$ & $\mathbf{2 0 0 0}$ & $\mathbf{2 0 2 5}$ & $\mathbf{2 0 5 0}$ \\
\hline Świat & 5,2 & 6,9 & 10,4 & $\mathbf{1 6 , 2}$ & 0,6 & 1,1 & 2,0 & 4,3 \\
\hline Rozwinięte & 7,9 & 14,3 & 20,8 & 26,2 & 1,0 & 3,1 & 5,5 & 9,5 \\
\hline Rozwijające się & 3,9 & 5,0 & 8,4 & 14,6 & 0,4 & 0,7 & 1,3 & 3,5 \\
\hline Afryka & 3,3 & 3,3 & 4,2 & 7,1 & 0,3 & 0,4 & 0,5 & 1,1 \\
\hline Azja & 4,1 & 5,7 & 9,9 & 17,3 & 0,4 & 0,8 & 1,7 & 4,4 \\
\hline Europa & 8,2 & 14,8 & 20,8 & 27,4 & 1,1 & 3,0 & 5,3 & 9,6, \\
\hline Ameryka Lacińska i Karaiby & 3,5 & 5,8 & 10,6 & 19,5 & 0,4 & 1,1 & 2,2 & 5,5 \\
\hline Ameryka Północna & 8,2 & 12,4 & 18,3 & 22,0 & 1,1 & 3,3 & 4,4 & 8,0 \\
\hline Oceania & 7,3 & 9,9 & 14,6 & 18,7 & 1,0 & 2,3 & 3,6 & 6,5 \\
\hline
\end{tabular}

Źródlo: United Nations (2009), World population prospects: The 2008 revision population database, United Nations, Department of Economic and Social Affairs, Population Division, New York.

Analiza powyższych danych jednoznacznie wskazuje, iż wzrost populacji osób starszych staje się zjawiskiem globalnym i dotyczy nie tylko społeczeństw państw rozwiniętych, co jest o tyle istotne, iż są to obszary o większej liczbie ludności niż Europa. Europa będąc dla reszty świata wyznacznikiem standardów w obszarze zabezpieczenia społecznego, sama czując narastający problem starzejących się społeczeństw, po raz kolejny może być swoistego rodzaju globalnym poligonem, jeśli chodzi o tworzenie realnych rozwiązań w tym obszarze. Warto zatem przyjrzeć się bardziej szczegółowo Europie, zwłaszcza Unii Europejskiej, gdyż ta społeczno-ekonomiczna wspólnota, de- 
klaruje chęć godzenia rozwoju ekonomicznego i społecznego. Tymczasem zrównoważony rozwój w tym obszarze musi w chwili obecnej uwzględniać interesy coraz to większej grupy osób starszych i konfrontować je z gwałtownym spadkiem liczby urodzeń oraz nie zawsze korzystnymi tendencjami w obszarze migracji.

Intensywne zmiany demograficzne mają miejsce w odniesieniu do poszczególnych państw Unii Europejskiej oraz Europejskiego Obszaru Gospodarczego (EOG), widać to na zestawieniach poniżej.

Tabela 3

Prognoza demograficzna dla poszczególnych państw UE w milionach oraz \%

\begin{tabular}{|c|c|c|c|c|c|c|c|}
\hline \multirow{2}{*}{ Państwo } & Zmiana 2013-2060 & 2013 & 2020 & 2030 & 2040 & 2050 & 2060 \\
\hline & $\mathbf{w} \%$ & \multicolumn{6}{|c|}{ w milionach } \\
\hline $\mathrm{BE}$ & 37,7 & 11,2 & 11,9 & 12,9 & 14,0 & 14,8 & 15,4 \\
\hline BG & $-24,8$ & 7,3 & 7,0 & 6,5 & 6,1 & 5,8 & 5,5 \\
\hline $\mathrm{CZ}$ & 5,4 & 10,5 & 10,7 & 10,8 & 10,9 & 11,1 & 11,1 \\
\hline DK & 16,5 & 5,6 & 5,8 & 6,1 & 6,3 & 6,4 & 6,5 \\
\hline $\mathrm{DE}$ & $-12,9$ & 81,3 & 80,6 & 79,7 & 77,7 & 74,5 & 70,8 \\
\hline $\mathrm{EE}$ & $-17,2$ & 1,3 & 1,3 & 1,2 & 1,2 & 1,1 & 1,1 \\
\hline IE & 14,3 & 4,6 & 4,6 & 4,6 & 4,7 & 5,0 & 5,3 \\
\hline EL & $-22,5$ & 11,0 & 10,7 & 10,1 & 9,6 & 9,1 & 8,6 \\
\hline ES & -1.0 & 46,6 & 45,7 & 44,5 & 44,7 & 45,6 & 46,1 \\
\hline FR & 15,1 & 65,7 & 67,8 & 70,5 & 72,9 & 74,4 & 75,7 \\
\hline HR & $-13,1$ & 4,3 & 4,2 & 4,1 & 4,0 & 3,8 & 3,7 \\
\hline IT & 10,1 & 60,2 & 62,1 & 64,2 & 66,3 & 67,0 & 66,3 \\
\hline $\mathrm{CY}$ & 29,5 & 0,9 & 0,9 & 0,9 & 1,0 & 1,0 & 1,1 \\
\hline $\mathrm{LV}$ & $-30,7$ & 2,0 & 1,9 & 1,6 & 1,5 & 1,5 & 1,4 \\
\hline LT & $-38,1$ & 3,0 & 2,6 & 2,2 & 2,0 & 1,9 & 1,8 \\
\hline $\mathrm{LU}$ & 110,5 & 0,5 & 0,6 & 0,8 & 0,9 & 1,1 & 1,1 \\
\hline $\mathrm{HU}$ & $-7,5$ & 9,9 & 9,8 & 9,7 & 9,5 & 9,3 & 9,2 \\
\hline MT & 12,7 & 0,4 & 0,4 & 0,5 & 0,5 & 0,5 & 0,5 \\
\hline $\mathrm{NL}$ & 1,6 & 16,8 & 17,2 & 17,6 & 17,6 & 17,4 & 17,1 \\
\hline AT & 14,3 & 8,5 & 8,8 & 9,3 & 9,6 & 9,7 & 9,7 \\
\hline PL & $-13,8$ & 38,5 & 38,4 & 37,5 & 36,2 & 34,8 & 33,2 \\
\hline PT & $-21,6$ & 10,5 & 10,1 & 9,8 & 9,4 & 8,8 & 8,2 \\
\hline $\mathrm{RO}$ & $-12,9$ & 20,0 & 19,7 & 19,0 & 18,4 & 17,9 & 17,4 \\
\hline SI & $-1,0$ & 2,1 & 2,1 & 2,1 & 2,1 & 2,1 & 2,0 \\
\hline SK & $-15,8$ & 5,4 & 5,4 & 5,3 & 5,1 & 4,9 & 4,6 \\
\hline FI & 14,8 & 5,4 & 5,6 & 5,9 & 6,1 & 6,2 & 6,2 \\
\hline SE & 36,3 & 9,6 & 10,2 & 11,0 & 11,8 & 12,5 & 13,1 \\
\hline UK & 25,0 & 64,1 & 66,9 & 70,6 & 74,0 & 77,3 & 80,1 \\
\hline NO & 60,5 & 5,1 & 5,6 & 6,4 & 7,1 & 7,7 & 8,2 \\
\hline EU28 & 3,1 & 507,2 & 512,8 & 518,8 & 523,7 & 525,5 & 522,8 \\
\hline EA & 2,0 & 334,5 & 337,7 & 341,4 & 344,6 & 344,6 & 341,2 \\
\hline
\end{tabular}

Źródło: European Union (2014), Underlying Assumptions and Projection Methodologies, „European Economy”, nr 8 , s. 17. 
Jak widać, prognozy demograficzne dotyczące Unii Europejskiej wskazują na zróżnicowanie dotyczące przyrostu ludności, w odniesieniu do poszczególnych państw członkowskich. Populacja w całej Unii wzrośnie o niespełna 15,6 miliona, jest to istotne z punktu widzenia gwałtownego wzrostu liczby osób w wieku $65+$ oraz spadku odsetka ludzi czynnych zawodowo w stosunku do osób w wieku poprodukcyjnym. Dodatkowo prognoza ta jest niekorzystna dla wielu państw z uwagi na znaczący spadek liczby ludności - należą do nich Polska, Bułgaria, Niemcy, Rumunia, Litwa, Łotwa, Portugalia, Grecja i Słowacja. Natomiast największy przyrost nastapi w Wielkiej Brytanii, Belgii, Francji, Włoszech, a z Europejskiego Obszaru Gospodarczego - w Norwegii. Jest to szczególnie istotne $\mathrm{z}$ punktu widzenia zachodzących, gwałtownych procesów wewnątrzmigracyjnych, mających związek z rozpowszechnionym zjawiskiem migracji zarobkowej, mogącej przekształcić się w osiedleńczą. Można wyraźnie wyodrębnić grupę zachowującą swój potencjał ludnościowy oraz grupę wyraźnie tracącą. Czynniki mające wpływ na taka, a nie inną prognozę są dwojakiego rodzaju, jednym z nich jest niewątpliwie niski przyrost naturalny, a także większe zainteresowanie migracją wewnętrzną oraz ciągłe zainteresowanie migracją z zewnątrz w przypadku takich państw jak Wielka Brytania, Francja, Włochy czy Norwegia.

Bardzo specyficzne i charakterystyczne dla tej sytuacji zestawienie może dotyczyć Polski i Norwegii, stanowiącej dla Polaków jeden z ważniejszych kierunków migracji zarobkowej, systematycznie przekształcającej się $\mathrm{w}$ osiedleńczą. W prognozowanym okresie ludność Polski ma się zmniejszyć o ponad 5 milionów mieszkańców, natomiast ludność niespełna 5 milionowej Norwegii ma wzrosnać o ponad 3 miliony. Przyrost naturalny w Polsce będący na poziomie 1,3 ma w prognozie wzrastać stopniowo do 1,6, natomiast w Norwegii ma utrzymać się na stabilnym poziomie 1,9. Równocześnie potencjał ludnościowy liderów UE, jakimi są Niemcy i Francja ma podobnie diametralnie różną prognoze, jak w przypadku Polski i Norwegii. W przypadku Niemiec ubytek ludności ma zmniejszyć się o ponad 10 milionów, natomiast Francji zwiększyć też o $10 \mathrm{mi}-$ lionów, współczynnik przyrostu naturalnego w przypadku Francji ma być na stabilnym poziomie 2,0, natomiast Niemiec ma być podobnie niski jak w Polsce. Niemcy, a także Polska nie są zdolne do wyrównania bilansu przy udziale imigrantów, ponieważ nie są tak atrakcyjne jak Norwegia czy Wielka Brytania, w której przyrost ma być dodatni, aż o 16 milionów, przy wysokim poziomie urodzeń 1,9 (European Union, 2015, s. 214).

Patrząc na problem z perspektywy prognozy demograficznej dotyczącej Europy Zachodniej należy mieć na uwadze, iż w 2030 roku połowa populacji będzie w wieku $50+$, a oczekiwana dalsza długość ich życia wyniesie 40 lat. Jest to ważne, ponieważ w grupie wiekowej $50+$ bardzo często dochodzi do zmian związanych ze spadkiem częściowej lub całkowitej aktywności na rynku pracy, ma to związek z chorobami, mniejszym dopasowaniem do istniejących warunków oraz funkcjonowaniem przywilejów emerytalnych dla wielu grup zawodowych (Policja itp.). Bardzo istotne, iż w tym samym czasie wydłuża się, w prognozach dotyczących UE, oczekiwana długość życia zarówno mężczyzn, jak i kobiet. Dla mężczyzn różnica ta ma wynieść 8,5 roku - 76 lat w 2008 do 84,5 lat w 2060 roku, a dla kobiety 6,9 lat - 82,1 lat w 2008 do 89 lat w 2060 roku (Carone, Eckefeld, 2010, s. 36).

Zmiany dotyczące długości życia powodują, iż z praktycznego punktu widzenia, istotne jest analizowanie zmian dotyczących osób starzejących się w grupie 65+, ma to 
uzasadnienie zarówno zdrowotne - wzrasta liczba schorzeń charakterystycznych oraz instytucjonalne - osiaganie ustawowego wieku emerytalnego. Jak widać, zmiany w połączeniu z wydłużeniem długości życia są niezwykle dynamiczne, a właściwie niespotykane na tę skalę, patrząc z perspektywy dziejów ludzkości. Obrazuje to zestawienie poniżej.

Tabela 4

Populacja osób powyżej 65 roku życia, jako \% ogólu

\begin{tabular}{|c|c|c|c|c|c|c|c|}
\hline Państwo & $\begin{array}{c}\text { Zmiana } \\
2013-2060\end{array}$ & 2013 & 2020 & 2030 & 2040 & 2050 & 2060 \\
\hline $\mathrm{BE}$ & 6,0 & 17,7 & 18,9 & 21,3 & 22,5 & 22,8 & 23,7 \\
\hline BG & 12,3 & 19,4 & 21,7 & 24,3 & 27,2 & 30,2 & 31,7 \\
\hline $\mathrm{CZ}$ & 11,1 & 17.1 & 20,2 & 22,3 & 24,7 & 27,5 & 28,2 \\
\hline DK & 6,6 & 18,0 & 20,0 & 22,4 & 24,0 & 23,6 & 24,6 \\
\hline $\mathrm{DE}$ & 11,3 & 21,0 & 23,2 & 28,1 & 31,2 & 31,8 & 32,3 \\
\hline $\mathrm{EE}$ & 11,7 & 18,2 & 20,6 & 24,3 & 26,8 & 28,8 & 29,9 \\
\hline IE & 9,0 & 12,4 & 15,0 & 19,4 & 23,1 & 24,9 & 21,4 \\
\hline EL & 12,7 & 20,3 & 22,1 & 25,8 & 30,7 & 33,9 & 33,0 \\
\hline ES & 12,1 & 17,9 & 20,1 & 25,3 & 31,0 & 33,3 & 30,0 \\
\hline FR & 7,1 & 17,8 & 20,3 & 23,2 & 25,2 & 25,1 & 24,8 \\
\hline HR & 11,3 & 18,3 & 20,7 & 24,2 & 26,3 & 28,4 & 29,6 \\
\hline IT & 8,8 & 21,2 & 22,4 & 25,3 & 28,9 & 29,9 & 30,0 \\
\hline $\mathrm{CY}$ & 13,4 & 13,4 & 16,3 & 20,5 & 23,1 & 25,5 & 26,8 \\
\hline LV & 9,2 & 18,9 & 20,7 & 25,5 & 27,9 & 28,3 & 28,0 \\
\hline LT & 7,5 & 18.3 & 20,7 & 27,7 & 30,8 & 28,3 & 25,8 \\
\hline $\mathrm{LU}$ & 7,8 & 14,0 & 14,8 & 16,8 & 18,6 & 19,9 & 21,8 \\
\hline $\mathrm{HU}$ & 12,1 & 17,4 & 20,3 & 21,9 & 24,7 & 27,6 & 29,5 \\
\hline MT & 11,0 & 17,5 & 21,2 & 24,4 & 24,8 & 26,4 & 28,5 \\
\hline $\mathrm{NL}$ & 10,3 & 17,1 & 20,0 & 24,3 & 27,0 & 26,9 & 27,4 \\
\hline AT & 10,7 & 18,2 & 19,5 & 23,5 & 26,4 & 27,4 & 28,9 \\
\hline PL & 18,5 & 14,5 & 18,4 & 22,7 & 25,1 & 29,9 & 33,0 \\
\hline PT & 14,9 & 19,6 & 22,4 & 26,8 & 31,6 & 34,6 & 34,6 \\
\hline RO & 12,5 & 16,4 & 18,9 & 20,8 & 25,1 & 27,8 & 28,9 \\
\hline SI & 12,1 & 17,3 & 20,6 & 25,0 & 27,9 & 29,9 & 29,4 \\
\hline SK & 21,9 & 13,3 & 16,9 & 21,6 & 25,5 & 31,3 & 35,2 \\
\hline FI & 7,0 & 19,1 & 22,1 & 24,5 & 24,4 & 24,7 & 26,0 \\
\hline SE & 4,9 & 19,3 & 20,4 & 21,5 & 22,5 & 22,5 & 24.2 \\
\hline UK & 7,5 & 17.3 & 18,7 & 21,4 & 23,3 & 23,9 & 24.8 \\
\hline $\mathrm{NO}$ & 7,5 & 15,8 & 17,1 & 19,0 & 20,7 & 21,5 & 23,3 \\
\hline EU28 & 10,0 & 18,4 & 20,5 & 24,1 & 27,0 & 28,2 & 28,4 \\
\hline EA & 9,7 & 19,2 & 21,3 & 25,1 & 28,3 & 29,2 & 28,9 \\
\hline
\end{tabular}

Źródło: European Union (2015), The 2015 Ageing Report: Economic and budgetary projections for the 28 EU Member States (2013-2060), „European Economy”, nr 3, s. 219. 
Interpretacja powyższych danych wskazuje jednoznacznie, iż na całym analizowanym obszarze populacja osób w wieku 65+ przekroczy w 2060 roku 1/4 ogółu ludności. W kilku państwach, między innymi w Polsce, Słowacji, Portugalii, Włoszech, Hiszpanii, Estonii, Niemczech i Bułgarii będzie to ponad 30\% ogółu populacji. Tymczasem w Norwegii i Francji, wskaźnik ten będzie utrzymywał się na poziomie poniżej 25\%. Po raz kolejny widoczny jest efekt przyrostu naturalnego w połączeniu $\mathrm{z}$ ich atrakcyjnością dla potencjalnych imigrantów. Bardziej dynamiczne, a tym samym niekorzystne z punktu widzenia rozwoju demograficznego zmiany, dotyczą nie tylko nowych państw członkowskich, przykładem może być Polska. Równie niekorzystne zmiany mają miejsce w państwach starej unii, tutaj głównym przykładem mogą być Niemcy. Jak zostanie to przedstawione w dalszej części artykułu, ma to związek $\mathrm{z}$ dwoma istotnymi czynnikami mającymi bezpośredni wpływ na sytuację demograficzną, są nimi spadek przyrostu naturalnego oraz procesy migracyjne.

Mając na uwadze, iż zapotrzebowanie na opiekę, a także nieuchronność pewnych schorzeń tj. zespoły otępienia $w$ tym najbardziej znana choroba Alzheimera, wzrasta wraz z ilością osób powyżej 80 roku życia, trzeba obserwować i prognozować działania w odniesieniu do tej grupy osób. O skali zjawiska i czekających Unię Europejską wyzwaniach świadczy zestawienie poniżej.

Tabela 5

Ilość osób starszych (powyżej 80 roku życia) jako \% ogólu populacji

\begin{tabular}{|c|c|c|c|c|c|c|c|}
\hline Państwo & $\begin{array}{c}\text { Zmiana } \\
2013-2060\end{array}$ & 2013 & 2020 & 2030 & 2040 & 2050 & 2060 \\
\hline 1 & 2 & 3 & 4 & 5 & 6 & 7 & 8 \\
\hline $\mathrm{BE}$ & 3,6 & 5,3 & 5,4 & 6,1 & 7,5 & 8,7 & 8,9 \\
\hline $\mathrm{BG}$ & 7,8 & 4,4 & 4,9 & 6,7 & 8,3 & 9,6 & 12,2 \\
\hline $\mathrm{CZ}$ & 7,6 & 3,9 & 4,2 & 6,6 & 7,9 & 8,4 & 11,5 \\
\hline DK & 5,5 & 4,2 & 4,8 & 7,0 & 7,9 & 9,3 & 9,7 \\
\hline $\mathrm{DE}$ & 7,9 & 5,5 & 7,4 & 8,2 & 10,6 & 14,2 & 13,4 \\
\hline $\mathrm{EE}$ & 7,0 & 4,8 & 6,1 & 7,2 & 9,3 & 10,4 & 11,8 \\
\hline IE & 7,3 & 2,9 & 3,5 & 5,3 & 7,1 & 8,7 & 10,2 \\
\hline EL & 9,5 & 5,8 & 7,1 & 8,1 & 10,1 & 12,9 & 15,3 \\
\hline ES & 9,4 & 5,6 & 6,2 & 7,7 & 9,8 & 12,7 & 14,9 \\
\hline FR & 4,9 & 5,7 & 6,0 & 7,5 & 9,4 & 10,4 & 10,6 \\
\hline HR & 6,7 & 4,4 & 5,3 & 6,2 & 8,7 & 9,9 & 11,1 \\
\hline IT & 6,8 & 6,3 & 7,1 & 8,1 & 9,3 & 11,9 & 13,1 \\
\hline $\mathrm{CY}$ & 6,5 & 3,0 & 3,8 & 5,6 & 7,4 & 8,5 & 9,5 \\
\hline LV & 6,3 & 4,7 & 5,9 & 7,1 & 9,2 & 10,6 & 11,0 \\
\hline $\mathrm{LT}$ & 6,5 & 4,9 & 6,2 & 7,7 & 10,4 & 12,5 & 11,4 \\
\hline LU & 3,9 & 3,9 & 4,1 & 4,4 & 5,6 & 7,1 & 7,8 \\
\hline $\mathrm{HU}$ & 7,5 & 4,1 & 4,6 & 6,1 & 8,1 & 8,6 & 11,7 \\
\hline MT & 6,7 & 3,8 & 4,9 & 7,8 & 9,6 & 9,4 & 10,5 \\
\hline $\mathrm{NL}$ & 6,9 & 4,2 & 4,9 & 7,1 & 9,1 & 11,3 & 11,1 \\
\hline $\mathrm{AT}$ & 6,1 & 5,0 & 5,5 & 6,8 & 8,4 & 11,2 & 11,1 \\
\hline PL & 8,5 & 3,8 & 4,4 & 5,8 & 9,2 & 9,5 & 12,3 \\
\hline
\end{tabular}




\begin{tabular}{|l|r|r|r|r|r|r|r||}
\hline \multicolumn{1}{|c|}{1} & 2 & 3 & 4 & 5 & 6 & 7 & 8 \\
\hline PT & 10,7 & 5,4 & 6,6 & 8,1 & 10,5 & 13,3 & 16,1 \\
\hline RO & 7,7 & 3,9 & 4,7 & 5,5 & 7,7 & 9,0 & 11,5 \\
\hline SI & 7,8 & 4,6 & 5,5 & 6,8 & 9,6 & 11,1 & 12,4 \\
\hline SK & 10,1 & 3,0 & 3,3 & 5,0 & 7,9 & 9,4 & 13,1 \\
\hline FI & 4,8 & 5,0 & 5,6 & 7,9 & 9,4 & 9,7 & 9,8 \\
\hline SE & 3,7 & 5,2 & 5,3 & 7,2 & 7,6 & 8,5 & 8,9 \\
\hline UK & 4,8 & 4,7 & 5,1 & 6,6 & 7,7 & 9,3 & 9,5 \\
\hline NO & 4,1 & 4,4 & 4,1 & 5,6 & 6,6 & 7,8 & 8,5 \\
\hline EU28 & 6,7 & 5,1 & 5,9 & 7,2 & 9,1 & 11,0 & 11,8 \\
\hline EA & 7,0 & 5,5 & 6,4 & 7,6 & 9,6 & 11,9 & 12,5 \\
\hline
\end{tabular}

Źródlo: European Union (2015), The 2015 Ageing Report: Economic and budgetary projections for the 28 EU Member States (2013-2060), ,European Economy”, nr 3, s. 220.

W tym przypadku również powtarza się podobne zestawienie jak poprzednio. Najwyższy procentowy udział w tej grupie, przekraczający $12 \%$, występuje w Niemczech, Grecji, Hiszpanii, Włoszech, Polsce, Bułgarii oraz Portugalii. Należy przy tym zauważyć, iż Polska czy Bułgaria nie należą do państw o najwyższej oczekiwanej długości życia, zatem w tych przypadkach decydujący jest niski przyrost naturalny oraz straty ludnościowe związane z migracją. Najniższy odsetek jest natomiast w Belgii, Danii, Francji, Norwegii, Szwecji i Luksemburgu, chociaż oczekiwana długość życia jest w nich najwyższa zarówno w odniesieniu do kobiet, jak i mężczyzn. Podobnie decydujący jest wysoki przyrost naturalny oraz bilans migracyjny, związany z atrakcyjnością tych państw, związaną również z tworzeniem przez państwa atrakcyjnych warunków dla imigrantów.

Tendencji związanej ze wzrostem ilościowym ludności świata określonej mianem starszych, będzie towarzyszył spadek liczby ludzi młodych do 15 roku życia. Prognozuje się, iż w połowie XXI wieku ich procentowy udział wyrówna się, w okresie 2000-2050 ilość mieszkańców Ziemi po 60 roku życia podwoi się z 10 do 21\% ogółu populacji, spadnie procentowy udział młodych z 30 do $21 \%$ (Political Declaration, 2002, s. 15). Jest to związane ze wspomnianym już wcześniej, postępującym na całym świecie spadkiem liczby urodzeń, co w obecnej chwili odczuwalne jest najbardziej w państwach rozwiniętych. Jednak, jak wskazuje przykład Chin, proces ten jest narastający w miarę rozwoju gospodarczego i coraz to bardziej konsumpcyjnego nastawienia ludzi młodych, wykreowanym stylem życia, w którym dążenie do wolności i samorealizacji nie idzie w parze $z$ dążeniem do tworzenia związków i posiadania dzieci. Stąd prognozy spadku liczby urodzin dotyczą całego świata, ponieważ stopniowy wzrost jest odczuwalny globalnie, wielu analityków twierdzi, iż kolejnym obszarem intensywnych zmian może być Afryka. Co w perspektywie krótkookresowej jest korzystne, natomiast w kontekście starzenia się może doprowadzić do jeszcze większej zapaści i rywalizacji międzypokoleniowej.

W państwach o najwyższych standardach socjalnych, do których niewątpliwie zaliczane są państwa UE, starzenie się społeczeństw związane jest z koniecznością obrony istniejącego poziomu bezpieczeństwa socjalnego. Nie jest to takie proste, gdyż wydhużenie dhugości życia i spadek liczby urodzeń powodują i będą powodowały systema- 
tyczny wzrost obciążeń finansowych w odniesieniu do funkcjonujących systemów emerytalnych. Sytuacje kryzysowe dotyczące państw i społeczeństw, jak pokazuje przykład Grecji, są związane z koniecznością dokonania cięć budżetowych kosztem, między innymi, emerytur osób uzależnionych od tych źródeł dochodu. Istniejące systemy emerytalno-rentowe opierają się na ugruntowanych w XX wieku systemach bazujących na transferze międzypokoleniowym, w których gwarancja wypłacalności była nierozerwalnie związana z proporcjami pomiędzy ilością osób pracujących i świadczeniobiorców. Źródłem wysokich świadczeń były i nadal są liczne i wysokowydajne, a także płacące składki osoby zawodowo czynne. Tymczasem ilość tych osób systematycznie maleje, co osłabia obecne systemy, należy przy tym zwrócić uwage, iż gwarantem systemowej wypłacalności są państwa. O skali zmian świadczą zestawienia tabelaryczne poniżej.

Tabela 6

Populacja osób zawodowo czynnych (15-64), jako \% ogólu spoleczeństwa

\begin{tabular}{|c|c|c|c|c|c|c|c|}
\hline Państwo & $\begin{array}{c}\text { Zmiana } \\
2013-60\end{array}$ & 2013 & 2020 & 2030 & 2040 & 2050 & 2060 \\
\hline 1 & 2 & 3 & 4 & 5 & 6 & 7 & 8 \\
\hline $\mathrm{BE}$ & $-5,9$ & 65,3 & 63,6 & 61,3 & 60,4 & 60,0 & 59,4 \\
\hline $\mathrm{BG}$ & $-12,7$ & 67,0 & 64,1 & 62,3 & 59,5 & 55,7 & 54,2 \\
\hline $\mathrm{CZ}$ & $-11,6$ & 68,0 & 63,8 & 63,0 & 60,6 & 56,7 & 56,4 \\
\hline DK & $-5,7$ & 64,6 & 63,4 & 60,7 & 59,0 & 59,9 & 58,9 \\
\hline $\mathrm{DE}$ & $-11,5$ & 66,1 & 64,0 & 59,0 & 56,2 & 55,5 & 54,6 \\
\hline $\mathrm{EE}$ & $-11,1$ & 66,0 & 62,8 & 61,0 & 58,9 & 55,6 & 54,9 \\
\hline IE & $-5,6$ & 65,7 & 63,4 & 63,1 & 59,3 & 55,7 & 60,1 \\
\hline EL & $-10,9$ & 65,1 & 63,9 & 61,9 & 57,0 & 53,2 & 54,2 \\
\hline ES & $-10,4$ & 66,9 & 65,4 & 63,0 & 57,1 & 53,4 & 56,5 \\
\hline FR & $-5,7$ & 63,7 & 61,6 & 59,1 & 57,2 & 57,4 & 57,9 \\
\hline HR & $-10,4$ & 66,9 & 64,4 & 61,4 & 59,9 & 57,7 & 56,5 \\
\hline IT & $-8,2$ & 64,8 & 63,8 & 61,4 & 57,6 & 56,5 & 56,5 \\
\hline $\mathrm{CY}$ & $-12,5$ & 70,2 & 67,0 & 64,0 & 63,0 & 59,7 & 57,7 \\
\hline $\mathrm{LV}$ & $-10,9$ & 66,6 & 63,8 & 60,4 & 58,3 & 55,7 & 55,7 \\
\hline LT & $-10,5$ & 67,0 & 64,0 & 57,7 & 55,4 & 55,0 & 56,5 \\
\hline LU & $-7,7$ & 69,0 & 67,9 & 65,2 & 63,5 & 62,7 & 61,3 \\
\hline $\mathrm{HU}$ & $-12,1$ & 68,2 & 65,3 & 63,7 & 61,1 & 58,1 & 56,1 \\
\hline MT & $-11,9$ & 68,0 & 63,9 & 60,2 & 60,7 & 58,7 & 56,1 \\
\hline $\mathrm{NL}$ & $-8,5$ & 65,9 & 64,0 & 59,9 & 57,3 & 57,9 & 57,3 \\
\hline AT & $-10,3$ & 67,4 & 66,0 & 61,9 & 59,6 & 58,7 & 57,1 \\
\hline PL & $-16,4$ & 70,5 & 66,3 & 63,7 & 62,2 & 56,9 & 54,1 \\
\hline PT & $-11,6$ & 65,7 & 64,6 & 61,5 & 56,7 & 53,8 & 54,1 \\
\hline $\mathrm{RO}$ & $-12,1$ & 68,0 & 65,5 & 63,8 & 60,0 & 57,0 & 55,8 \\
\hline SI & $-12,2$ & 68,2 & 64,0 & 61,0 & 58,5 & 55,3 & 55,9 \\
\hline SK & $-18,0$ & 71,4 & 68,1 & 65,6 & 62,8 & 56,9 & 53,3 \\
\hline FI & $-6,7$ & 64,5 & 61,2 & 59,0 & 59,3 & 58,9 & 57,8 \\
\hline $\mathrm{SE}$ & $-5,4$ & 63,8 & 61,6 & 60,4 & 60,2 & 59,9 & 58,4 \\
\hline
\end{tabular}




\begin{tabular}{|l|c|c|c|c|c|c|c||}
\hline \hline 1 & 2 & 3 & 4 & 5 & 6 & 7 & 8 \\
\hline UK & $-7,0$ & 65,1 & 63,0 & 60,8 & 59,6 & 58,8 & 58,0 \\
\hline NO & $-6,3$ & 65,9 & 64,7 & 62,7 & 61,4 & 61,1 & 59,7 \\
\hline EU28 & $-9,4$ & 66,0 & 63,9 & 61,1 & 58,4 & 56,9 & 56,6 \\
\hline EA & $-9,0$ & 65,5 & 63,8 & 60,6 & 57,4 & 56,3 & 56,5 \\
\hline
\end{tabular}

Źródlo: European Union (2015), The 2015 Ageing Report: Economic and budgetary projections for the $28 \mathrm{EU}$ Member States (2013-2060), „European Economy”, nr 3, s. 219.

Tabela 7

Osoby w wieku 80 i więcej lat, jako \% populacji zawodowo czynnej

\begin{tabular}{|c|c|c|c|c|c|c|c|}
\hline Państwo & $\begin{array}{c}\text { Zmiana } \\
2013-60\end{array}$ & 2013 & 2020 & 2030 & 2040 & 2050 & 2060 \\
\hline $\mathrm{BE}$ & 6,8 & 8,1 & 8,6 & 9,9 & 12,5 & 14,4 & 15,0 \\
\hline $\mathrm{BG}$ & 15,9 & 6,5 & 7,6 & 10,8 & 14,0 & 17,2 & 22,5 \\
\hline $\mathrm{CZ}$ & 14,7 & 5,7 & 6,5 & 10,5 & 13,0 & 14,8 & 20,4 \\
\hline DK & 10,0 & 6,4 & 7,5 & 11,6 & 13,4 & 15,6 & 16,4 \\
\hline $\mathrm{DE}$ & 16,2 & 8,3 & 11,6 & 13,9 & 18,9 & 25,6 & 24,5 \\
\hline EE & 14,2 & 7,3 & 9,6 & 11,7 & 15,8 & 18,7 & 21,5 \\
\hline $\mathrm{IE}$ & 12,6 & 4,5 & 5,6 & 8,4 & 11,9 & 15,6 & 17,0 \\
\hline EL & 19,3 & 8,9 & 11,0 & 13,1 & 17,7 & 24,3 & 28,3 \\
\hline ES & 18,1 & 8,3 & 9,5 & 12,2 & 17,2 & 23,8 & 26,4 \\
\hline FR & 9,4 & 8,9 & 9,8 & 12,6 & 16,4 & 18,1 & 18,3 \\
\hline HR & 13,1 & 6,5 & 8,3 & 10,1 & 14,5 & 17,2 & 19,6 \\
\hline IT & 13,5 & 9,8 & 11,2 & 13,2 & 16,2 & 21,1 & 23,3 \\
\hline $\mathrm{CY}$ & 12,2 & 4,2 & 5,6 & 8,7 & 11,8 & 14,2 & 16,4 \\
\hline LV & 12,6 & 7,1 & 9,3 & 11,8 & 15,8 & 18,9 & 19,7 \\
\hline LT & 12,9 & 7,3 & 9,8 & 13,3 & 18,8 & 22,7 & 20,2 \\
\hline LU & 7,0 & 5,7 & 6,0 & 6,7 & 8,8 & 11,3 & 12,7 \\
\hline $\mathrm{HU}$ & 14,7 & 6,1 & 7,0 & 9,6 & 13,2 & 14,9 & 20,8 \\
\hline MT & 13,1 & 5,6 & 7,7 & 12,9 & 15,9 & 16,0 & 18,7 \\
\hline $\mathrm{NL}$ & 12,9 & 6,4 & 7,6 & 11,9 & 15,9 & 19,5 & 19,4 \\
\hline AT & 12,1 & 7,4 & 8,4 & 11,0 & 14,0 & 19,0 & 19,5 \\
\hline PL & 17,3 & 5,4 & 6,6 & 9,1 & 14,9 & 16,8 & 22,7 \\
\hline PT & 21,5 & 8,3 & 10,2 & 13,2 & 18,5 & 24,6 & 29,7 \\
\hline $\mathrm{RO}$ & 15,0 & 5,7 & 7,1 & 8,6 & 12,8 & 15,9 & 20,7 \\
\hline SI & 15,5 & 6,7 & 8,6 & 11,2 & 16,5 & 20,1 & 22,2 \\
\hline SK & 20,3 & 4,2 & 4,9 & 7,6 & 12,6 & 16,5 & 24,5 \\
\hline FI & 9,2 & 7,7 & 9,1 & 13,5 & 15,8 & 16,5 & 16,9 \\
\hline SE & 7,1 & 8,1 & 8,5 & 12,0 & 12,7 & 14,2 & 15,2 \\
\hline UK & 9,1 & 7,2 & 8,1 & 10,9 & 12,8 & 15,8 & 16,3 \\
\hline $\mathrm{NO}$ & 7,6 & 6,6 & 6,4 & 8,9 & 10,8 & 12,7 & 14,2 \\
\hline EU28 & 13,1 & 7,7 & 9,2 & 11,8 & 15,5 & 19,3 & 20,8 \\
\hline EA & 13,7 & 8,4 & 10,1 & 12,6 & 16,6 & 21,1 & 22,1 \\
\hline
\end{tabular}

Zródło: European Union (2015), The 2015 Ageing Report: Economic and budgetary projections for the $28 \mathrm{EU}$ Member States (2013-2060), „European Economy”, nr 3, s. 221. 
Również tutaj widoczna jest wcześniejsza tendencja. $Z$ jednej strony państwa o niższym procentowym udziale osób $80+$ w porównaniu do zawodowo czynnych, równoległy z wysokim udziałem osób zawodowo czynnych, jako części całej populacji, dotyczy to Belgii, Francji, Danii, Szwecji czy Norwegii. Z drugiej strony państwa o niskim procentowym udziale ludności zawodowo czynnej - Bułgaria, Niemcy, Polska, Grecja oraz Portugalia i jednocześnie wysokim wskaźniku w odniesieniu do osób 80+.

Już dzisiaj widoczne są światowe tendencje związane z chęcią zapewnienia bezpieczeństwa społecznego pokoleniom $65+\mathrm{i}$ więcej. $\mathrm{Z}$ jednej strony państwa takie jak Chiny zmierzają do jak najszybszego stworzenia sprawnych, funkcjonujących na wzór istniejących w Europie systemów emerytalno-rentowych. Jest to podyktowane wspomnianą już wcześniej, charakterystyczną dla społeczeństw konsumpcyjnych gwałtowną migracją setek milionów ludzi do miast i pozbawieniem ich naturalnego wsparcia w postaci rodziny i skromnej egzystencji na wsi. Jest to szczególnie istotne $\mathrm{z}$ uwagi na zauważalnąjuż dzisiaj tendencję spadku dzietności wśród nowych mieszkańców miast. Z drugiej strony pozbawiona od lat tradycyjnych powiązań rodzinnych, zamieszkująca głównie miasta starzejąca się ludność Europy, boryka się z problemem zapewnienia opieki ludziom w podeszłym wieku, związanym między innymi z kurczeniem się ilości osób zawodowo czynnych.

W przypadku Europy, już w II połowie XX wieku skłoniło to wiele społeczeństw do zreformowania swoich systemów emerytalnych tak, by promowały większą indywidualną zapobiegliwość w sferze zabezpieczenia na starość, a nie tylko liczenie na państwo. Nie jest to efektywne i równorzędne we wszystkich państwach, ponieważ widocznie zaznacza się podział na pragmatyczną północ i gorzej zorganizowane południe, a także kontestujące konieczność reform społeczeństwa z Europy Środkowo-Wschodniej.

Najlepszym tego przykładem mogą być zmuszeni kryzysem do zaakceptowania zmian w swoim systemie emerytalnym Grecy, kuszeni przez polityków perspektywą obniżenia wieku emerytalnego Polacy i walczący o prawo do dłuższego zatrudnienia oraz zakaz zwolnień z uwagi na wiek Norwegowie.

Patrząc na procesy związane ze starzejącą się Unią warto przeanalizować konsekwencje tego procesu w odniesieniu do kondycji finansowej samych zainteresowanych oraz przyszłych obciążeń dla budżetu oraz istniejących systemów.

\section{Wyzwania migracyjne}

Migracja we wszystkich jej aspektach - emigracji, imigracji czy też reemigracji niesie za sobą różne konsekwencje dla państw i społeczeństw, których dotyczy. Patrząc na Europę z perspektywy migracji, należy mieć na uwadze, iż począwszy od lat 50-tych $\mathrm{XX}$ wieku, z uwagi na zmiany ekonomiczne i powojenne zapotrzebowanie rynków pracy, była ona miejscem napływu wielu milionów osób z zewnątrz. Skala migracji powoli słabła w latach 80 -tych XX wieku. Było to wynikiem zarówno nasycenia rynków pracy, jak i coraz większej społecznej niechęci i braku akceptacji dla nowych imigrantów zewnętrznych.

Obecną prognozę demograficzną związaną z saldem migracyjnym wyraźnie pokazuje zestawienie poniżej. Należy przy tym zauważyć, iż została ona sporządzona w roku 
2014. Sytuacja UE zwłaszcza w kontekście dwóch nowych zjawisk, intensywnej migracji wewnętrznej, zauważanej od początku rozszerzenia z 2004 roku oraz rosnącej presji nielegalnej imigracji po roku 2011, zmienia się niezwykle dynamicznie. Dlatego trudno jednoznacznie przewidzieć skalę migracji zewnętrznej, związanej z chęcią osiedlenia się na obszarze bogatej $\mathrm{i}$ bezpiecznej UE setek tysięcy obywateli z zewnątrz.

Tabela 8

Migracja netto (saldo migracji) w tysiącach oraz \% ogólu populacji

\begin{tabular}{|c|c|c|c|c|c|c|c|c|}
\hline Państwo & $\begin{array}{c}\text { Zmiana } \\
\text { 2013-2060 }\end{array}$ & 2013 & 2020 & 2030 & 2040 & 2050 & 2060 & $\begin{array}{c}\text { Imigranci jako \% } \\
\text { ogólu populacji } \\
2060\end{array}$ \\
\hline $\mathrm{BE}$ & $-19,1$ & 61,2 & 80,2 & 80,9 & 69,8 & 46,8 & 42,1 & 20,7 \\
\hline $\mathrm{BG}$ & 3,5 & $-2,9$ & $-5,8$ & $-5,8$ & 5,3 & 3,7 & 0,6 & $-0,4$ \\
\hline $\mathrm{CZ}$ & 22,5 & $-1,3$ & 28,0 & 35,8 & 40,7 & 25,5 & 21,2 & 13,0 \\
\hline DK & $-11,2$ & 21,2 & 18,9 & 19,9 & 16,3 & 10,5 & 10,0 & 11,5 \\
\hline $\mathrm{DE}$ & 1224,9 & $-1127,0$ & 228,7 & 220,2 & 142,6 & 119,3 & 97,9 & 9,9 \\
\hline $\mathrm{EE}$ & 2,7 & $-2,7$ & $-3,7$ & $-2,2$ & 0,6 & 0,6 & 0,0 & $-4,5$ \\
\hline IE & 47,5 & $-32,4$ & $-30,3$ & $-12,1$ & 4,8 & 16,7 & 15,1 & $-4,0$ \\
\hline $\mathrm{EL}$ & 20,6 & $-15,9$ & $-22,3$ & $-10,0$ & 1,3 & 7,3 & 4,7 & $-3,0$ \\
\hline ES & 585,9 & $-310,9$ & $-79,0$ & 87,5 & 225,2 & 305,6 & 275,0 & 14,1 \\
\hline FR & 14,0 & 52,8 & 90,2 & 91,2 & 84,0 & 74,2 & 66,8 & 5,2 \\
\hline HR & 2,5 & 2,3 & 2,4 & 3,5 & 4,6 & 5,7 & 4,8 & 5,2 \\
\hline IT & $-939,1$ & 1135,5 & 348,1 & 382,4 & 335,9 & 214,8 & 196,4 & 23,4 \\
\hline $\mathrm{CY}$ & 8,5 & $-0,6$ & $-0,6$ & 2,8 & 6,0 & 8,8 & 7,9 & 19,0 \\
\hline LV & 10,1 & $-10,1$ & $-14,3$ & $-9,9$ & 0,9 & 0,7 & 0,0 & $-16,9$ \\
\hline LT & 16,8 & $-16,8$ & $-37,4$ & $-21,1$ & 1,0 & 0,4 & 0,0 & $-33,0$ \\
\hline LU & $-5,7$ & 10,5 & 11,7 & 11,2 & 9,1 & 5,4 & 4,9 & 37,5 \\
\hline $\mathrm{HU}$ & 5,9 & 8,1 & 24,3 & 20,9 & 24,2 & 15,3 & 14,0 & 10,3 \\
\hline MT & $-0,5$ & 1,6 & 1,6 & 1,5 & 1,4 & 1,3 & 1,1 & 14,4 \\
\hline NL & $-12,8$ & 22,1 & 24,2 & 23,5 & 13,0 & 8,9 & 9,3 & 4,7 \\
\hline AT & $-30,8$ & 55,5 & 51,3 & 51,9 & 41,9 & 27,2 & 24,8 & 20,6 \\
\hline PL & 27,1 & $-15,6$ & 2,9 & $-0,9$ & 25,4 & 29,5 & 11,6 & 1,8 \\
\hline PT & 48,2 & $-40,3$ & 0,3 & 9,2 & 11,9 & 8,3 & 7,9 & 2,7 \\
\hline $\mathrm{RO}$ & 11,6 & $-9,2$ & 0,4 & $-24,7$ & 11,6 & 7,1 & 2,4 & $-0,2$ \\
\hline SI & 3,7 & 0,8 & 4,1 & 4,6 & 5,5 & 5,4 & 4,5 & 11,0 \\
\hline SK & 0,4 & 2,0 & 3,0 & 2,5 & 4,7 & 4,7 & 2,4 & 3,5 \\
\hline FI & $-8,3$ & 17,2 & 22,0 & 21,7 & 17,7 & 9,6 & 8,9 & 13,0 \\
\hline $\mathrm{SE}$ & $-34,6$ & 65,8 & 55,3 & 56,0 & 49,1 & 34,7 & 31,2 & 17,4 \\
\hline UK & 6,2 & 165,0 & 172,1 & 203,3 & 209,3 & 190,2 & 171,2 & 11,4 \\
\hline NO & $-16,8$ & 39,2 & 53,4 & 51,8 & 42,3 & 24,9 & 22,4 & 24,1 \\
\hline EU28 & 1000,8 & 35,9 & 976,3 & 1244,1 & 1363,8 & 1188,3 & 1036,7 & 10,5 \\
\hline $\mathrm{EA}$ & 967,1 & $-197,4$ & 677,7 & 936,0 & 977,3 & 866,2 & 769,6 & 11,8 \\
\hline
\end{tabular}

Źródło: European Union (2014), Underlying Assumptions and Projection Methodologies, „European Economy”, $\operatorname{nr} 8$, s. 16 . 
Jak wynika z powyższego zestawienia w prognozowanym okresie czasu Unia Europejska nadal pozostaje obszarem, w którym imigracja stanowi znaczący element bilansu ludnościowego. Nie jest on jednak równomiernie rozłożony na poszczególne państwa członkowskie. Jednoznaczny przyrost, a co za tym idzie wysoki procentowy udział imigrantów w populacji, następuje w przypadku państw strefy EURO oraz EOG, co jest wyraźnie widoczne na przykładzie Belgii, Luksemburga, Włoch, Austrii oraz Norwegii. Procentowy, prognozowany przyrost ludności ma wynieść w Luksemburgu -110,6\%; Norwegii - 60,5\%; Belgii - 37,7\%; Szwecji 36,3\%. Natomiast spadek i niski lub ujemny procentowy udział imigrantów jest widoczny w Bułgarii, Estonii, Irlandii, Grecji, Łotwie, Litwie, Rumunii oraz Polsce. Widoczny przyrost imigrantów we Włoszech ma niewątpliwy związek z obecną sytuacją rosnącej liczby imigrantów z Afryki oraz Bliskiego Wschodu. Natomiast Belgia, Austria czy Norwegia są dzięki poziomowi rozwoju oraz swojej polityce imigracyjnej, postrzegane jako bardzo atrakcyjne. Co się tyczy ujemnego czy bardzo niskiego salda wśród nowych państw członkowskich, a także Grecji czy Irlandii to wiąże się ono z małą atrakcyjnością tych państw z punktu widzenia potencjalnych imigrantów. Trzeba zwrócić uwagę na dramatyczny wręcz ubytek ludności, szacowany w państwach o dużym nasileniu emigracji dla: Bułgarii $(-24,0 \%)$; Estonii $(-17,9 \%)$; Grecji $(-22,5 \%)$; Lotwy $(-30,7 \%)$; Litwy $(-38,1 \%)$; Polski $(-13,8 \%)$; Portugalii $(21,6 \%)$ czy Niemiec $(-12,9 \%)$. W przypadku Niemiec widoczny jest stopniowy spadek atrakcyjności tego państwa dla kolejnych imigrantów oraz coraz większe obawy tego państwa w odniesieniu do grup potencjalnych nowych przybyszów.

Mając na uwadze wcześniejsze odniesienie do Polski i Norwegii, można zastanowić się, na ile ujemny bilans demograficzny w Polsce oraz dodatni w Norwegii, będzie wynikał z dynamicznego wzrostu liczby naszych obywateli zamieszkujących w tym państwie? Ilu nowych obywateli Norwegii będzie miało swoje korzenie w Polsce? Najlepiej sytuację te przedstawia bilans migracji do Norwegii na przestrzeni 10 lat po przystapieniu Polski do UE, a tym samym otwarciu norweskiego rynku pracy na Polaków.

Tabela 9

Obcokrajowcy przybyli do Norwegii w latach 2004-2014 dane ilościowe oraz wzrost ich populacji w \%

\begin{tabular}{|l|c|c|c|}
\hline \multicolumn{1}{|c|}{ Państwo } & $\mathbf{1 . 0 1 . 2 0 0 4}$ & $\mathbf{1 . 0 1 . 2 0 1 4}$ & Wzrost w \% \\
\hline Polska & 2 & 3 & 4 \\
\hline Szwecja & 7590 & 91179 & 68 \\
\hline Somalia & 22870 & 38414 & 130 \\
\hline Litwa & 15586 & 35912 & 3694 \\
\hline Pakistan & 937 & 35546 & 31 \\
\hline Irak & 26286 & 34447 & 74 \\
\hline Niemcy & 17295 & 30144 & 138 \\
\hline Wietnam & 11232 & 26683 & 25 \\
\hline Dania & 17414 & 21721 & 8 \\
\hline Filipiny & 19318 & 20897 & 170 \\
\hline Iran & 7374 & 19886 & 47 \\
\hline
\end{tabular}




\begin{tabular}{|l|c|c|c|}
\hline \multicolumn{1}{|c|}{1} & 2 & 3 & 4 \\
\hline Rosja & 7457 & 18770 & 152 \\
\hline Turcja & 12971 & 17345 & 34 \\
\hline Bośnia i Hercegowina & 15216 & 16845 & 11 \\
\hline Tajlandia & 5910 & 16559 & 180 \\
\hline Afganistan & 4851 & 15459 & 219 \\
\hline Sri Lanka & 11918 & 14797 & 35 \\
\hline Wielka Brytania & 10945 & 14774 & 557 \\
\hline Erytrea & 2191 & 14397 & 85 \\
\hline Indie & 6836 & 12924 & 655 \\
\hline Rumunia & 1466 & 11068 & \\
\hline
\end{tabular}

Źródlo: Aftenposten. Lørdag 26. april 2014, s. 10.

Kwestie związane z bezpieczeństwem UE oraz poszczególnych państw członkowskich powoduja, iż nie ma społecznego i politycznego przyzwolenia na politykę imigracyjna, o podobnym charakterze jak w okresie po II wojnie światowej. Jest to niewątpliwie związane z rosnącymi zagrożeniami związanymi z terroryzmem, zwłaszcza o podłożu islamskim. Nie bez znaczenia jest dramatyczna sytuacja na południu Europy, będąca konsekwencją tzw. Arabskiej wiosny ludów (Nowiak, 2014), powodująca problemy w państwach leżących nad Morzem Śródziemnym oraz obawy państw docelowych, tj. Wielka Brytania, Niemcy, Francja czy Regionu Nordyckiego. Stąd mimo początkowych obaw bardzo duże otwarcie na ruchy migracyjne wewnątrz UE, pobudzone rozszerzeniem z 2004 roku i otwarciem obywatelom tych państw rynków pracy. Powoduje to i będzie nadal powodowało odpływ ludzi młodych z Polski do państw migracyjnych tj. Wielka Brytania, Irlandia, Niemcy czy Norwegia. Konsekwencje tego są widoczne już dzisiaj, a będą jeszcze bardziej odczuwalne w obliczu postępującego starzenia.

Tak długo, jak Polska oraz inne kraje dotknięte ujemnym bilansem demograficznym są mniej atrakcyjnym miejscem dla potencjalnych imigrantów, niż państwa do których emigrują ich obywatele, można jedynie przygotowywać się na narastającą skalę problemu. Jedną z podstawowych wartości UE jest wolność przemieszczania się, stąd jedynie świadome wybory obywateli mogą zahamować skalę wewnętrznej migracji, stanowiącej dzisiaj, w obliczu wyzwań demograficznych związanych ze starzeniem się, zagrożenie dla części państw członkowskich. Można użyć stwierdzenia, iż można się przygotowywać na swoistego rodzaju rywalizację o nowych imigrantów w gronie dzisiejszych państw członkowskich.

\section{Uwarunkowania i wyzwania rozsądnego kompromisu}

We współczesnej Europie i świecie rozsądny kompromis musi dotyczyć zrównoważonego rozwoju zarówno na płaszczyźnie społecznej, ekonomicznej, jak i technologicznej. Wysiłki związane z przeniesieniem zagadnień zrównoważonego rozwoju na sfery nie tylko środowiskowe, są podejmowane od dłuższego czasu przez instytucje europejskie, przykładem tych działań może być tworzenie strategii w tym zakresie (COM, 2009, 400 final). W odniesieniu do przedstawionych w poprzedniej części fak- 
tów oraz prognoz dotyczących starzejących się społeczeństw, cała społeczność międzynarodowa, wspólnoty regionalne takie jak UE oraz poszczególne państwa muszą zintensyfikować uczestnictwo osób starszych w obecnych procesach rozwojowych. Zmiany społeczno-ekonomiczne, również procesy społeczno-kulturowe dotyczące sfery świadomości, wymagają propagowania kontynuacji jak najdłuższego zaangażowania ludzi starszych tak, by postępujące procesy atomizacji rodzin, nie powodowały zwiększonej ich izolacji i marginalizacji. Potrzebny jest rozsądny kompromis, dostrzeżenie problemów starzejącego się świata, w tym Europy, zawarty pomiędzy pokoleniami oraz decydentami politycznymi, niezależnie od ich przynależności partyjnych. Procesy migracyjne, zwłaszcza w obecnej sytuacji społeczno-politycznej, nie mogą i nie będą wydajne, jeśli chodzi o zahamowanie obecnych tendencji dotyczących starzenia się społeczeństw europejskich. Tylko wybrane państwa, dzięki swojej atrakcyjności społeczno-ekonomicznej są i będą zdolne do czerpania z wewnątrzunijnego kapitału ludzkiego. Tak, jak przedstawiono wcześniej dla jednych jest to duża szansa (Austria, Belgia, Norwegia), dla innych katastrofa demograficzna i zapaść systemowa w obszarze bezpieczeństwa socjalnego osób starszych (Litwa, Lotwa, Polska). Dlatego w ocenie autora, szeroko rozumiany kompromis powinien dotyczyć trzech głównych sfer, związanych z funkcjonowaniem starzejących się społeczeństw:

1) zapewnienia osobom starszym większego uczestnictwa w życiu społecznym oraz innowacyjnej gospodarce tak, by mogli oni być konsumentami tych zmian, zarówno w formie aktywnej, jak i pasywnej. W szczególności osoby starsze powinny:

a) mieć zapewnioną możliwość kontaktu i współuczestniczenia w życiu pozostałych członków społeczeństwa we wszystkich wymiarach życia zbiorowego,

b) zapewnione aktywne uczestniczenie w procesach decyzyjnych dotyczących zarówno nich samych, jak i spraw ogólnospołecznych. Konieczność uwzględniania ich interesów,

c) mieć możliwość maksymalnie długiego funkcjonowania i aktywności zgodnie z ich życzeniem i możliwościami na rynku pracy. Dostosowywanie rynków pracy do ich możliwości i potrzeb i zapobieganie marnotrawstwu kapitału ludzkiego,

d) być dopuszczonymi w pełnym zakresie do edukacji, nauki oraz korzystania z możliwości praktycznych tak, by mogli oni kontynuować swoją aktywność zawodową i społeczna,

e) mieć możliwość pełnego wykorzystania przez resztę społeczeństwa ich zdolności zawodowych, społecznych i doświadczenia z uwzględnieniem możliwości czerpania przez nich z tego tytułu benefitów. Praktycznym rozwiązaniem jest wydłużanie wieku emerytalnego i zachęty powrotu na rynek pracy,

f) uzyskiwać ciagłe wsparcie i możliwość kreowania pozytywnego wizerunku osób starszych zarówno w ich najbliższym otoczeniu, jak i świecie. Jest to istotne z punktu widzenia narastającej, chwilowej rywalizacji międzypokoleniowej, widocznej zwłaszcza na rynku pracy;

2) zapewnienie osobom starszym możliwości utrzymania dobrej kondycji psycho-fizycznej, pomimo postępujących procesów starzenia. W szczególności osoby starsze powinny:

a) mieć możliwość, gwarancje takiego środowiska życia, które sprzyja ich integracji i aktywności, 
b) nie być skazanymi na marginalizację z uwagi na miejsce zamieszkania, co w szczególności może dotyczyć regionów wiejskich,

c) zapewnienie możliwości zachowania w tej grupie dobrego zdrowia oraz tężyzny fizycznej,

d) dostosowywanie środowiska życia osób starszych do ich rosnących potrzeb opiekuńczych. Istotnym elementem rozwiązań w tym zakresie mogą być możliwości związane z wykorzystaniem nowych technologii;

3) zapewnienie osobom starszym wspierającego ich otoczenia, w szczególności:

a) zapewnienie im równego dostępu do wszystkich dóbr i usług, dostępnych pozostałym grupom wiekowym,

b) korzystania z mechanizmów solidarności międzypokoleniowej,

c) mieć zagwarantowane mechanizmy eliminujące w tej grupie zagrożenie ubóstwem,

d) zapewnianie opieki i wsparcia medycznego w skali adekwatnej do rosnących potrzeb tej grupy. Również w tym obszarze istnieją duże możliwości związane z wykorzystywaniem nowoczesnych technologii,

e) tworzenie systemów wsparcia nastawionych na odciążenie rodziny i równoczesne umożliwienie jak najbliższego kontaktu osób potrzebujących opieki poza medycznej z rodziną oraz otoczeniem. W tym przypadku istotne jest wcześniejsze tworzenie infrastruktury oraz kształcenie kadr opiekuńczych tak, by mogły one sprostać nadchodzącym wyzwaniom.

Przedstawione powyżej hasłowe propozycje nie wyczerpują listy postulatów, zarysowują jedynie kierunki działań. Wiele $\mathrm{z}$ nich funkcjonuje już na gruncie europejskim w państwach o rozwiniętym systemie usług społecznych oraz propagujących jak najdłuższą aktywność zawodową i społeczną seniorów (Austria, Niemcy, Holandia, Norwegia, Szwecja). Wiele potrzebuje głębokich reform sięgających nie tylko infrastruktury, istotna jest również sfera świadomości społecznej, akceptacji zmian koniecznych z uwagi na nadchodzące prognozy demograficzne. O tym, że nie jest to łatwe świadczą realia polskie oraz formy toczącej się debaty związanej z wydłużaniem wieku emerytalnego czy polityki rodzinnej. Przykłady docierające z Chin wskazują, iż również inni mogą dążyć do realizacji pragmatycznych rozwiązań społecznych na wzór europejski, ponieważ wymuszają to istniejące i przyszłe realia demograficzne (Oksanen, 2012). Trudno prognozować na ile są one możliwe do realizacji w innych częściach świata, można jedynie stwierdzić, iż są konieczne.

\section{Zakończenie}

Powyższy artykuł nie jest, bo nie taki był jego cel, wyczerpującą analizą podjętych w temacie zjawisk. Może on, zdaniem autora, być przyczynkiem do szerszej refleksji i kontynuacji tematu badawczego. Ukazuje problem jakim w świecie, Europie oraz poszczególnych państwach staje się współistnienie istotnych zjawisk społecznych - zmian demograficznych (starzenie, spadek liczby urodzin) i procesów migracyjnych. Migracja jako jeden ze współistniejących problemów, tylko częściowo czy wręcz wybiórczo, może rozwiązać współczesne problemy demograficzne Europy. Najkorzyst- 
niejszym rozwiązaniem jest migracja wewnętrzna, ponieważ zyskać można zarówno kapitał ludzki, istotny dla starzejącej i wyludniającej się przestrzeni europejskiej, jak i oczekiwany przyrost naturalny. Niestety z tego rozwiązania mogą korzystać jedynie najatrakcyjniejsi społeczno-ekonomiczni gracze. Swoistego rodzaju propozycje dotyczące ewentualnych działań wyprzedzających kryzys, zostały zawarte w części nakreślającej istotę kompromisu. Muszą to być wybory związane z szeroką akceptacją społeczną, oparte na rezygnacji z rywalizacji pokoleniowej oraz politycznej. W ocenie autora ten kompromis jest konieczny czy możliwy do osiągnięcia? Czy jesteśmy gotowi na zmiany? O tym zarówno w przypadku świata, Unii Europejskiej, jak i Polski zdecydują niezwykle dynamiczne zmiany społeczno-ekonomiczne i społeczno-kulturowe obserwowane w chwili obecnej. Im szybciej i bardziej pragmatycznie przygotujemy się na nie i wypracujemy kompromis, tym lepiej dla samych zainteresowanych, a jesteśmy nimi wszyscy.

\section{Bibliografia}

Carone G., Eckefeld P. (2010), Making use of long-term demographic projections in multilateral policy coordination in the EU, in: Work session on demographic projections, Lisbon, 28-30 April 2010, Publications Office of the European Union, Luxembourg.

China 2030: Building a Modern, Harmonious, and Creative Society (2013), The World Bank.

European Union (2014), Underlying Assumptions and Projection Methodologies, „European Economy", nr 8, Brussel.

European Union (2015), The 2015 Ageing Report: Economic and budgetary projections for the 28 EU Member States (2013-2060), „European Economy”, nr 3, Brussel.

Geyer R. (2003), Beyond the Third Way: The Science of Complexity and the Politics of Choice, „British Journal of Politics and International Relations", vol. 5, s. 237-257.

Harper S. (2006), Ageing societies: Myths, challenges and opportunities, London.

Oksanen H. (2012), China: Pension Reform for an Aging Economy, w: R. Holtzman, E. Palmer. D. Robalino, Nonfinancial Defined Contribution Pension Schemes in a Changing Pension World, vol. 1: Progress, Lessons, and Implementation, World Bank.

Political Declaration and Madrid International Plan of Action on Ageing, Swcond World Assambly on Ageing, Madrid, Spain, 8-12 April 2002, (2002), United Nation, New York.

Rubinson C., Ragin C. C. (2007), New methods for comparative research?, w: Capitalisms compared, eds L. Mjoset, T. H. Clausen, Elsevier, Oxford, s. 373-389.

Nowiak W. (2014), Arabska wiosna a kwestie bezpieczeństwa Izraela i jego sasiadów, „Przegląd Politologiczny", nr 1.

Vienna International Plan of Action on Aging (1983), United Nation, New York.

2009 Review of the European Union Strategy for Sustainable Development, COM (2009) 400 final. 24.07.2009.

\section{Streszczenie}

Nie ulega wątpliwości, iż współcześnie obserwowany, globalny proces starzenia się społeczeństw ma charakter zmian demograficznych nie obserwowanych w dotychczasowych dziejach 
ludzkości. To zmiany demograficzne są największym wyzwaniem dotyczącym społeczeństw, rynków pracy oraz gospodarek. Celem tego artykułu jest przedstawienie w jaki sposób spadek liczby urodzeń, starzenie się społeczeństw oraz wzrost migracji wpływa na zmiany w Unii Europejskiej oraz całym świecie globalnym.

Słowa kluczowe: migracje, starzenie się, polityka społeczna, bezpieczeństwo narodowe

\section{Ageing of societies and migration - two fundamental challenges for Europe in the 2010s. Are we ready for change?}

\section{Summary}

There is no doubt that the current rapid increase in population ageing across the globe signifies unprecedented demographic changes in the history of humankind. Demographic changes are among the most important challenges facing societies, labour markets and economies. This paper analyses how low fertility rates, ageing populations, and the growing number of migrants from other countries are changing the face of the European Union and the entire global community.

Key words: migration, ageing, social policy, national security 